\section{International Scientific Journal Theoretical \& Applied Science}

p-ISSN: 2308-4944 (print) e-ISSN: 2409-0085 (online)

Year: $2015 \quad$ Issue: $11 \quad$ Volume: 31

Published: $30.11 .2015 \quad \underline{\text { http://T-Science.org }}$

SECTION 2. Applied mathematics. Mathematical modeling.
Mohiniso Bahromovna Hidirova

$\mathrm{PhD}$, Senior Scientist, dept."Regulatorika"

Centre for the development of software and hardware program complexes at Tashkent University of Informational Technologies, Tashkent, Uzbekistan regulatorika@yahoo.com

Zaynabhon Djumanazarovna Yusupova Senior teacher of dept. "System and applied programming"

Tashkent University of Informational Technologies Tashkent, Uzbekistan zaynabhon@inbox.ru

\title{
ANALYSIS MECHANISMS OF CARDIAC TISSUE EXCITEMENT TAKING INTO ACCOUNT DELAY IN REGULATION SYSTEM
}

\begin{abstract}
Increasing interest in quantitative studies of mechanisms of cardiac tissue excitements is stipulated by the absence of generally accepted models for origin and developments of many cardiac diseases, including arrhythmia and sudden cardiac death. In the article the differential equations of cardiac cellular systems excitement with taking into account temporary relations in regulation system of cardiac activity are considered.

Key words: excitation of the cardiac tissue, differential-difference equation, modeling of regulatory mechanisms of the heart, delay time.

Language: English

Citation: Hidirova MB, Yusupova ZD (2015) ANALYSIS MECHANISMS OF CARDIAC TISSUE EXCITEMENT TAKING INTO ACCOUNT DELAY IN REGULATION SYSTEM. ISJ Theoretical \& Applied Science 11 (31): 59-62.

Soi: http://s-o-i.org/1.1/TAS-11-31-10 Doi: crossef http://dx.doi.org/10.15863/TAS.2015.11.31.10

It is considered that the cardiovascular system is a major integrative, that is central, in terms of life support the body. Cardiovascular diseases currently represent a serious problem for human health. Therefore it is required to study the mechanisms of functioning of the heart as a whole. There is a sufficient number of techniques, allowing versatile study the state of the heart. So today, a number of software and hardware systems, allows us to observe the reconstruction of the anatomical structure of the atria and visualize the dynamics of excitation: CARTO BiosenseWebster (USA); EnSite Endocardial Solutions (USA); Bhotok3D Scientific and Production Association (Tomsk); Elcart Navigator II IPC "Electropulse (Tomsk). Graphic course of the pulse excitation of the heart muscle allows us to understand the mechanisms of arrhythmias and the possibility of predestination possible changes after exposure. These models have the ability to visualize the essence of the excitation dynamics. However, they do not have adequate predictive function evaluation. Nevertheless, in certain situations, only one imaging is extremely insufficient. Current research on modeling the dynamics of excitation (the heart as a whole, and

individual departments) focused on research or the heart as an object of study, or simulation of the properties of the active medium with separate its characteristic effects. In clinical practice, these techniques are not widely used due to their complexity. Also, due to the high cost of building expensive individual model. And the possibility of using ready-made templates making impossible due to the uniqueness of each of them. In this regard, the study of the regulatory mechanisms of the heart with the help of mathematical modeling is very important [1-5]. O.I. Adebisi, I.A.Adejumobi, I.O. Abiala and S.O. Omotainse [6] tried to create a mathematical model of cardiac electrical activity, in order to understand the different mechanisms of the heart and abnormal heart condition. The electrical activity of the cardiac heart tissue, presented in this paper was based on a coupling consideration bidomain model and the ionic model FitzHugh-Nagumo [7], taking into account the closed boundary conditions between the intracellular and extracellular domains to give a complete description of the propagation of electrical waves through the heart tissue. The complete system of differential equations describing the cardiac function of the form [7]:
\end{abstract}




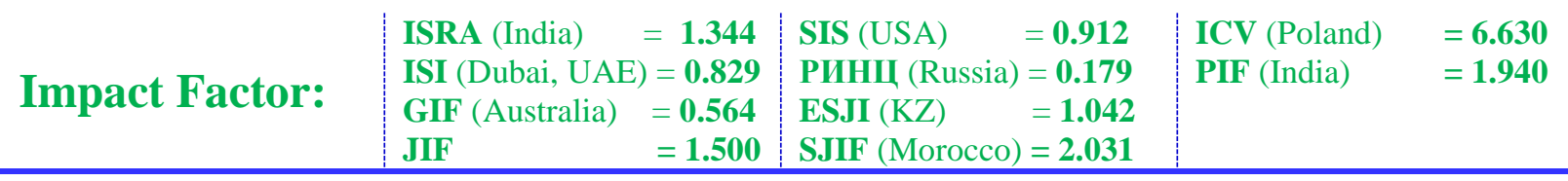

$$
\left\{\begin{array}{l}
-\nabla \cdot\left(\left(\sigma_{i}+\sigma_{\varepsilon}\right) \nabla \phi_{\varepsilon}\right)=\nabla \cdot\left(\sigma_{i} \nabla V_{m}\right) \quad \text { в } \quad \Omega_{H} \\
-\nabla \cdot\left(\sigma_{i} \nabla V_{m}\right)+\nabla \cdot\left(\sigma_{i} \nabla \phi_{\varepsilon}\right)=\chi_{m}\left(C_{m} \frac{\partial V_{m}}{\partial t}+I_{i o n}\left(V_{m}, w\right)-I_{a p p}\right) \quad \text { в } \quad \Omega_{H} \\
\frac{d w}{d t}=g\left(V_{m}, w\right) \quad \text { в } \quad \Omega_{H} \\
I_{i o n}=\frac{1}{\varepsilon_{1}}\left(V_{m}-\frac{V_{m}^{3}}{3}-w\right) \\
g=\varepsilon_{2}\left(V_{m}-\gamma w+\beta\right) \\
V_{m}(x, 0)=V_{m}^{0}(x), \forall x \in \Omega_{H} \\
w(x, 0)=w^{0}(x), \forall x \in \Omega_{H} \\
\sigma_{i} \nabla \phi_{i} \cdot n=\sigma_{\varepsilon} \nabla \phi_{\varepsilon} \cdot n \quad \text { в } \Sigma
\end{array}\right.
$$

Where $\varepsilon_{1}, \varepsilon_{2}, \gamma, \beta$ are the main parameters in the model. They are positive.

The results obtained in this work are very useful in the study of the characteristic properties of the action potential in the detection of any irregularities in the electric wave propagation cardiac tissue. V.B.Koshelev, S.I.Muhin, N.V.Sosnin, A.P.Favorsky [8] studied the mathematical model of the cardiovascular system. In their work, they were limited to the construction of simplified models that reproduce the basic functions of the heart and allows you to physiologically reasonable flow in the vessels. Everyone knows that in the cardiovascular system, heart acts as a pump normally provides a periodic blood flow into the aorta and then in the whole circulatory system. Running this function of heart is possible only when heart is provided with enough blood from the venous part of the circulatory system. The available experimental data suggest the wellknown, for example, the relationship changes over time in blood flow $\left(S_{u}=q_{A}(t)\right)$ or the relationship changes over time in the pressure vessel $\left(p=p_{A}(t)\right)$ at the junction of the heart to the aorta. The pressure at the outlet from the ventricle within one cardiac period $T_{p}=\tau_{\mathrm{S}}+\tau_{\mathrm{d}}$ can be approximately described by the following function [8]:

$$
p_{A}(t)=\left\{\begin{array}{l}
p_{\text {top }}-\frac{1}{\tau_{s}^{2}}\left(p_{\text {top }}-p_{\text {bot }}\right)\left(t-\tau_{s}\right)^{2}, \quad 0 \leq t \leq \tau_{s} \\
p_{\text {bot }}, \tau_{s}<t \leq \tau_{s}+\tau_{d}
\end{array}\right.
$$

There $\tau_{\mathrm{S}}-$ systole time, $\tau_{\mathrm{d}}-$ diastole time, $\mathrm{p}_{\text {top }}$ and $p_{b o t}$ - the maximum and minimum values of the pressure at the outlet from the ventricle of the heart cycle.

$$
Q_{A}(t)=\left\{\begin{array}{l}
q_{t o p}-\frac{1}{\tau_{s}^{2}}\left(q_{t o p}-q_{b o t}\right)\left(t-\tau_{s}\right)^{2}, \quad 0 \leq t \leq \tau_{s} \\
q_{b o t}, \tau_{s}<t \leq \tau_{s}+\tau_{d}
\end{array}\right.
$$

The values of the parameters $q_{\text {top }}$ and $q_{b o t}$ associated with cardiac output $\mathrm{V}_{\mathrm{s}}$ of the heart period $\mathrm{T}_{\mathrm{p}}$ with the following relationship:

$$
V_{s}=\int_{t}^{t+T_{p}} Q_{A}(\xi) d \xi=\frac{2 q_{t o p}+q_{b o t}}{3} \tau_{s}+q_{b o t} \tau_{d}
$$

Modifying the parameters in the formula (1), (2) allows different modes of operation of the heart. This model assumes that the heart consists of two elements: atrial and ventricular.

In the above work the mathematical model constructed without delay during the propagation of excitation in parts of the heart and circulatory system. And it significantly affects the outcome of the study.
The modeling of the heart on the basis of quantitative description of excitation in the pacemaker, the atria and ventricles, and consistency of the feedback loop [3].

When considering the mechanisms of anomalies in the atria, ventricles, and in the pacemaker can be used the following system of equations of cardiac tissue excitement considering the average number of excited cells in the pacemaker, the atria and ventricles [9]: 


\begin{tabular}{l|lrl|l|ll} 
& ISRA (India) & $=\mathbf{1 . 3 4 4}$ & SIS (USA) & $=\mathbf{0 . 9 1 2}$ & ICV (Poland) & $=\mathbf{6 . 6 3 0}$ \\
Impact Factor: & ISI (Dubai, UAE) $=\mathbf{0 . 8 2 9}$ & PUHU (Russia) $=\mathbf{0 . 1 7 9}$ & PIF (India) & $=\mathbf{1 . 9 4 0}$ \\
& GIF (Australia) & $\mathbf{0 . 5 6 4}$ & ESJI (KZ) & $=\mathbf{1 . 0 4 2}$ & & \\
& JIF & $=\mathbf{1 . 5 0 0}$ & SJIF (Morocco) $=\mathbf{2 . 0 3 1}$ & &
\end{tabular}

$$
\begin{gathered}
\frac{d x(t)}{d t}=a_{1} \Theta\left(t-\tau_{0}\right) \eta\left(t-\tau_{0}\right) e^{-\delta_{1} \Theta\left(t-\tau_{0}\right)-\delta_{2} \eta\left(t-\tau_{0}\right)}-b_{1} x(t) \\
\frac{d y(t)}{d t}=a_{2} x\left(t-\tau_{1}\right)-b_{2} y(t) \\
\frac{d z(t)}{d t}=a_{3} x\left(t-\tau_{2}\right)-b_{3} z(t) \\
\frac{d \Theta(t)}{d t}=a_{4} y\left(t-\tau_{3}\right)-b_{4} \Theta(t) \\
\frac{d \eta(t)}{d t}=a_{5} z\left(t-\tau_{4}\right)-b_{5} \eta(t)
\end{gathered}
$$

Investigation of the stability of equilibrium states of non-trivial (3) conducted on the basis of qualitative and quantitative analysis on the PC, shows the presence of an unstable equilibrium position and the region of vibrational solutions that can be in the form of regular oscillations (limit cycles of Poincare type) and the irregular fluctuations. In some cases, in the computational experiments, there is a failure of the oscillations (the effect of "black hole"), which expresses a sudden cardiac death.

For the study, the most common patterns of behavior of the model, the qualitative analysis of regulation mechanisms of cardiac function in normal and anomalies can be seen following the reduced system

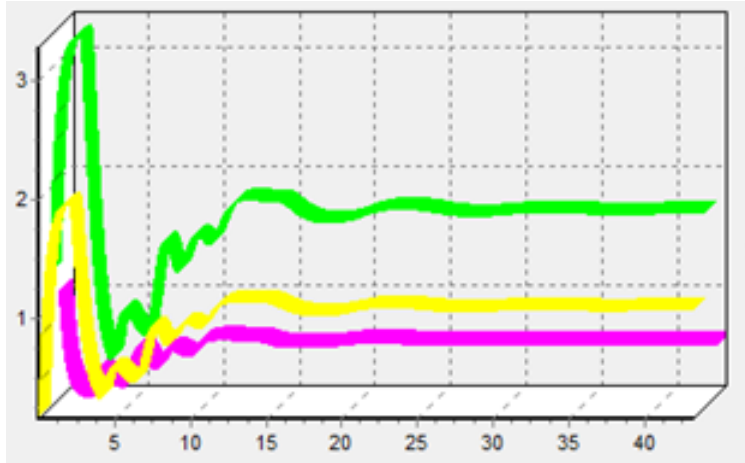

a)

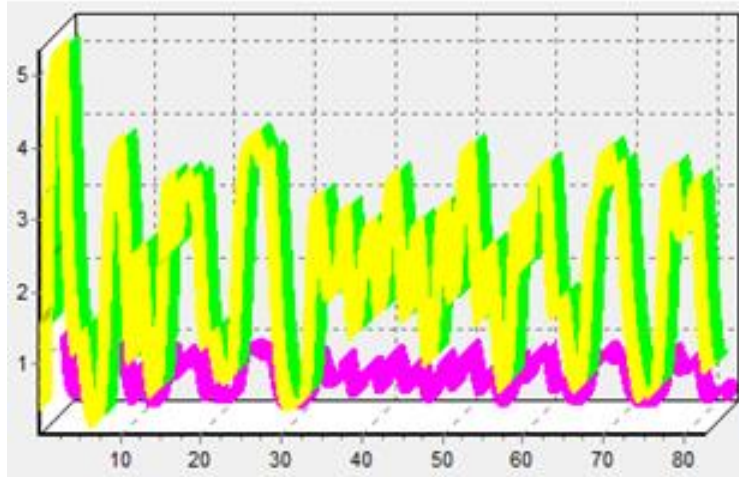

c)

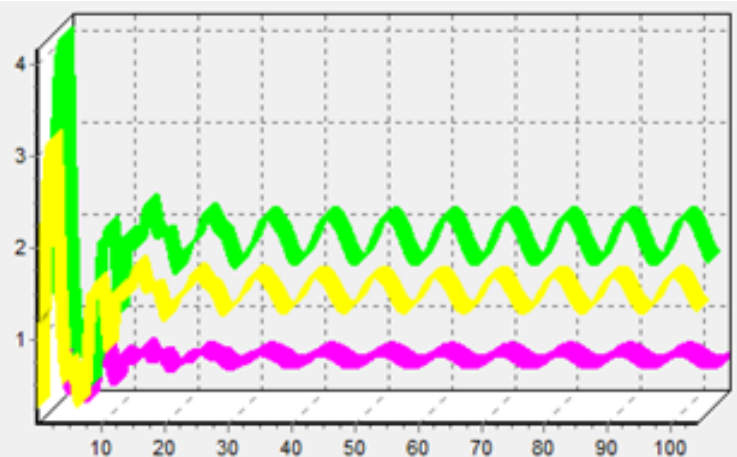

b)

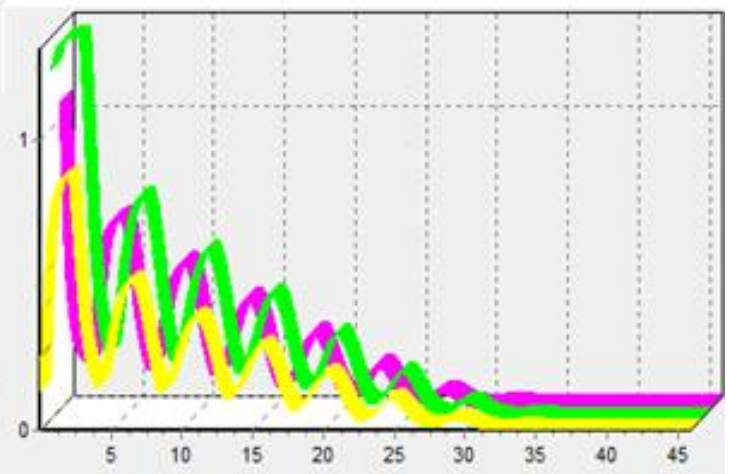

d)

Figure 1 - Basic behavior mode of solutions of (4).

(a - a stable stationary state, b - oscillations, c - irregular fluctuations, $d$ - damped oscillations). 


\begin{tabular}{|c|c|c|c|c|c|c|}
\hline Impact Factor: & $\begin{array}{l}\text { ISRA (India) } \\
\text { ISI (Dubai, UAE } \\
\text { GIF (Australia) } \\
\text { JIF }\end{array}$ & $\begin{array}{l}=1.344 \\
=0.829 \\
=0.564 \\
=1.500\end{array}$ & $\begin{array}{l}\text { SIS (USA) } \\
\text { PИНЦ (Russia) } \\
\text { ESJI (KZ) } \\
\text { SJIF (Morocco) }\end{array}$ & $\begin{array}{l}=0.912 \\
=0.179 \\
=1.042 \\
=2.031\end{array}$ & $\begin{array}{l}\text { ICV (Poland) } \\
\text { PIF (India) }\end{array}$ & $\begin{array}{l}=6.630 \\
=1.940\end{array}$ \\
\hline
\end{tabular}

$$
\begin{aligned}
& \frac{d X(t)}{d t}=a_{1} Y(t-1) Z(t-1) e^{-(Y(t-1)+Z(t-1))}-X(t) ; \\
& \frac{d Y(t)}{d t}=a_{2} X(t-1)-Y(t) ; \\
& \frac{d Z(t)}{d t}=a_{3} X(t-1)-Z(t)
\end{aligned}
$$

Qualitative analysis (4) shows that the system has one trivial and two nontrivial equilibrium positions. The trivial equilibrium position - stable, the first non-trivial equilibrium position is unstable, and the second is functional, ie, It may lose its stability with the occurrence of limit cycles, chaos and breakdown decisions.

Realization of the system of functionaldifferential delay equations in PC implemented by method of Bellman-Cook via delayed identifiers [1012]. Figure 1 shows the basic modes of behavior of the system solutions (4).

Thus, the model study of mechanisms of cardiac tissue excitement carried out by various differential equations. Depending on the task in the field of quantitative analysis of cardiac tissue excitement can be used bidomain model, equation FitzHugh-Nagumo and functional-differential equations, etc. Discussed in this article, the results of qualitative and quantitative analysis of the equations regulatory cardiac tissue excitement show the existence of oscillation, irregular fluctuations and the effect of "black hole". In the case of identification of a cardiac modes (normal, various forms of arrhythmia and sudden cardiac death, respectively) can be carried out modeling of specific diseases of the heart tissue and its corrected [11].

These studies was partly financed Support Fund for Basic Research, Academy of Sciences of Uzbekistan (grant № F4-FA-F006, grant № A-5005).

\section{References:}

1. Hidirova MB (2001) Biomechanics of cardiac activation: the simplest equations and modelling results // Russian Journal of Biomechanics, 2001. Vol. 5, № 2: 95-103.

2. Hidirova MB (1998) On a closed model of the cardiovascular system (CVS): Mechanics of cardiac tissue excitement // Problems of Mechanics. - 1998. - № 2. - pp. 39-43.

3. Hidirova MB (2003) Modelling of regulation mechanisms of cardiovascular systems. Scienticae Mathematicae Japonicae. Vol.8, 2003, pp. 427-432.

4. Hidirova MB (1998) On a closed model of the cardiovascular system (CVS): The rate and cardiac anomaly // Problems of Mechanics. 1998. - № 3. - pp. 29-33.

5. Hidirova MB (1998) On a closed model of the cardiovascular system (CVS): Basic equations and results of computational experiments // Problems of Mechanics. - 1998. - № 5. - pp. 2630.

6. Adebisi OI, Adejumobi IA, Abiala IO, Omotainse SO (2012) "Mathematical Modelling of Cardiac Electrical Activity Using
Bidomain Approach". Journal of Computations \& Modelling, vol.2, no.3, 2012, 109-126.

7. FitzHugh RA (1961) Impulses and physiological states in theoretical models of nerve membrane. Biophys.J. 1, 1961, pp. 445466.

8. Koshelev VB, Muhin SI, Sosnin NV, Favorsky AP (2010) Mathematical models of quasi-onedimensional hemodynamics. Toolkit. Moscow. Press, 2010. - 114 p.

9. Hidirova MB (2004) Modelling of mechanisms of cardiac excitation tissue.16 11, 2004 pp.3-14.

10. Hidirov BN (1984) On a method of studying regulation of living systems. // Problems of Cybernetics. - T., 1984. - Vol. 128. - pp. 41-46.

11. Hidirova MB (2014) Mathematical and computer modeling correction of cardiac tissue excitation in the area of anomalies // Proceedings of the XIV International conference "Computer science: problems, the methodology, technology", Voronezh, February 6-7, 2014, pp. 505-509.

12. Bellman R, Cook K (1967) Differentialdifference equations. Publishing house "Mir", Moscow, 1967, pp. 548. 